defined by the author as "an empirical examination of the genesis and development of some of the cultural values which underly the large-scale pursuit of science". The "Dictionary of National Biography" has been selected as the source of information of an occupational census and the data subjected to a tabulation process. On the basis of this information a further survey of discoveries based on Darmstaedter's "Handbuch zur Geschichte der Naturwissenschaften und Technik" was compiled. This indicated the particular interests which arose in different times in the period studied. The influence of religious movements such as Puritanism is considered. The influence of external factors is carefully examined. The whole study is very interesting and suggestive in many fields but suffers from the lack of a detailed table of contents, so that the intention of the work is not easy to grasp, and the author's conclusions are not easy to find in the mass of detail. Vol. 5 of Osiris, which now rejoices in a Latin title as Commentationes de scientiarum et eruditionis historia rationeque volumen quintum Iulio Ruska oblatum, is dated 1938, and is edited by Dr. Sarton assisted by Dr. Pogo. It contains some interesting and valuable papers on scientific incunabula (to which a recent volume of Osiris was devoted), on Arabic algebra (incidentally, the history of mathematics has occupied a prominent place in the journal so far), on Kopp, the historian of chemistry, on astronomy, on Michael Scot (a subject which has now been about worked to death), on animals in the Bible, and on other subjects. There is a biographical and bibliographical notice of Ruska and a portrait. These two volumes of Osiris maintain the high standard of scholarship of the publication, and are indispensable to students of the history of science.

\section{Royal Cornwall Polytechnic Society}

IN its several ways the Royal Cornwall Polytechnic Society continues to stimulate interest in the traditions and archæology of the county as well as in science. Lectures are given, prizes for essays awarded, excursions are made and much is done for meteorology by the maintenance of the Falmouth Observatory and the support of the Cornwall Rainfall Association. All these matters are referred to in the one hundred and fifth annual report, recently issued, which is accompanied by some of the original contributions to the Society. The Society was founded when the Cornish metalliferous mines were in full swing, and in a paper entitled "The Ancient Mining Districts of Cornwall" Mr. F. J. Stephens gives a review of the score or more of mines which existed within two miles of the coastline, in the parishes of Illogan, St. Agnes and Perranzabuloe. Another contribution, but in lighter vein, is an account of the opening of the railway to Falmouth in 1863 , from which it was hoped the district would gain much by the re-opening of the port of Falmouth as a terminus for steamship lines, while in yet another Mr. E. Chirgwin treats of the dialect of Cornwall. As in other parts of Great Britain, the dialect "is speeding from the presence of compulsory instruction, the cinema, the motor coach, the daily paper and the thousands of visitors" who flock to the district. As usual, Mr. W. T. Hooper gives a series of valuable meteorological notes, in which he shows that those discontented because perpetual sunshine is not to be enjoyed at Falmouth, have little about which to complain.

\section{Japan Institute for Science of Labour}

THE annual report of the director of the Japan Institute for Science of Labour for 1937 gives a brief account of the history of the Institute as well as of its divisions and functions (Tokyo: Japan Institute for Science of Labour, 1938. 70 sen). A programme of proposed investigations, including studies on nutrition and the prevention of industrial accidents and occupational disease, is also outlined which indicates how sadly warped the whole outlook of Japan has become under the demands of her policy of war and aggression. Brief notes are included on investigations completed in 1936-37, among which may be mentioned a study of dust in mail-cars and a survey of the labour conditions of railway postal workers. The first part of an investigation on gaseous metabolism in heavy muscular work has been completed, covering gaseous exchange in static effort, and a third report on occupational diseases of printers, especially lead poisoning, deals with the density of dust in the air and the window space in the printing shop. A statistical analysis has been made of the causes of death in different occupations, and other studies have included acute nicotine poisoning among land workers and water supply in an agricultural village.

\section{The Lily Year-book}

The Royal Horticultural Society's Lily Year-book for 1938 (London: the Society's Office, Vincent Square, S.W.1. Pp. $181+35$ plates. 5s. paper; 6s. cloth. 1938) contains an account by Messrs. A. B. Stout and W. M. Porterfield of "Seed Patterns and Incompatibilities in Lilium candidum". It is shown that incompatibilities may occur among sister plants of the same species. Such disabilities are physiological in nature, and are not to be confused with failures in hybridizing fertilizations. An ingenious method of estimating incompatibility by the examination of seeds has been used. The results are considered in relation to the practical promotion of fertility by late fertilization, when suitable stigmatic secretion is developed, and by artificial treatments of the stigma. The Year-book contains numerous papers about the horticultural treatment of lilies; Dr. Fred Stoker has a useful article upon the geographical origin and classification of the Carniolicum group of lilies; Mr. A. D. Cotton con. tributes a short biography of Père Armand David (1826-1900), the celebrated naturalist and explorer; and Mr. E. O. Clement describes various practices for the germination of lily seed in Ontario. The year's work upon lilies revealed by the volume indicates a lack of contributions of a fundamentally scientific nature. Reports of discussions at meetings of the Society's Lily Group, published in the present Yearbook (pp. 42-79), and similar accounts in earlier 